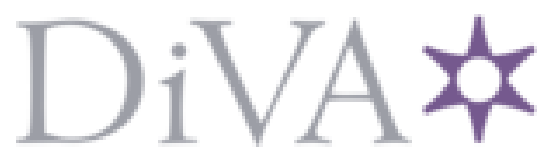

http://www.diva-portal.org

\title{
Postprint
}

This is the accepted version of a paper published in Ethics and Education. This paper has been peer-reviewed but does not include the final publisher proof-corrections or journal pagination.

Citation for the original published paper (version of record):

Dahlbeck, J. (2017)

The egoistic teacher: educational implications of Spinoza's ethical egoism

Ethics and Education, 12(3): 304-319

https://doi.org/10.108o/17449642.2017.1343653

Access to the published version may require subscription.

N.B. When citing this work, cite the original published paper.

Permanent link to this version:

http://urn.kb.se/resolve?urn=urn:nbn:se:mau:diva-2999 
Author: Johan Dahlbeck

Title of article: The egoistic teacher: educational implications of Spinoza's ethical egoism

Author's affiliation: Malmö University, Sweden

Visiting address: Nordenskiöldsgatan 10, OR:A228, Malmö, Sweden

E-mail: johan.dahlbeck@mah.se

Phone: +46 733127941

Abstract: In this paper I suggest that Spinoza's understanding of virtue and collective flourishing, rooted in his psychological and ethical egoism, offers a fresh perspective on the question of egoism in education. To this end, I suggest an understanding of the teacher as egoist, where the self-seeking of the teacher is conditioned by - and runs parallel to - the flourishing of his or her students. The understanding of the egoistic teacher is offered as a productive counter-image to the altruistic ideal in education as well as to the commonplace conception of the teacher as primarily a provider of services and the student as a consumer on an educational market.

Key words: Spinoza; ethical egoism; psychological egoism; egoistic teacher 


\section{The Egoistic Teacher: Educational Implications of Spinoza's Ethical Egoism}

\section{Introduction: Egoism and Education}

Egoism and education are two concepts in tension with one another. Typically, education insofar as education is broadly conceived as an ethical enterprise - is regarded as an antidote to both small-mindedness and selfishness. From this perspective to be educated is to come to know the world, and by coming to know the world we enter into a community with others, gaining a perspective that allows us to look beyond the restrictions of our own personal wants and needs so as to contribute to a common world that is believed to be something more than the sum of its parts. Education, in this sense, is construed as a systematic combating of egoism and its supposedly dire consequences for the human social world.

At the same time, it is difficult to deny that egoism functions as a very basic psychological driving force in our daily lives. Arguably we do many of the things we do because we hope to gain something from it. Of course, some of the things we hope to gain are more noble (such as an increased understanding) than other things (such as wealth and reputation), but all of it is in some sense fueled by self-interest. If this is so then egoism cannot be disregarded altogether but must be taken into account as a necessary factor in all human affairs. Education, being a largely human affair, therefore has to take egoism into account.

In this paper I aim to address the question of egoism and education in a way that I hope will shed new light on the enduring debate of what role egoism plays in education. Rather than approaching egoism as a necessary evil, however, I will construe an account of education where the egoism of the teacher and the students is taken to be a productive and foundational force. In order to do this I will draw on Spinoza's psychological egoism, arguing that this can help construct an ethical account of education where benevolence is conditioned by rational self-seeking and where the teacher's desire to teach is taken to be grounded in the fundamentally egoistic desire to persevere in being rather than in an altruistic impulse to help others.

\section{Problematic Aspects of the Altruistic Ideal in Education}

In contemporary educational philosophy there is an ongoing debate on the problems with asserting a commonsensical notion of the good teacher as self-evidently altruistic (Higgins, 2003; 2011). Likewise, there is a surge in interest in addressing some of the more taken for granted assumptions of progressive education concerning the benefits of student-centeredness and the importance of avoiding unpleasant experiences in education (Mintz, 2012; Jonas, 2010). These debates are closely related to the debate on the role of egoism in education insofar as they go to the heart of what education is and what it ought to be and to the question of where this leaves the teacher and the students.

Chris Higgins, in his The Good Life of Teaching (2011), argues that the altruistic ideal in education is widespread yet fundamentally flawed. It hinges, he claims, on a set of assumptions that do not necessarily add up. These are (1) that ' $[t]$ eaching is a deeply moral endeavor in which the welfare of other human beings, their current vulnerabilities and their future possibilities, is the teacher's primary concern'; (2) that since 'acting on this concern requires a high degree of selflessness and sacrifice ... [t]eachers who are self-absorbed, or 
trying to meet their own needs vicariously through their teaching, betray the moral core of teaching'; and, consequently (3) that 'good teaching is a selfless labour of love' and 'the best teachers simply decide that the good they accomplish for others makes their own sacrifice worthwhile, and carry on indefinitely in the name of benevolent service' (pp. 170-171). Higgins questions the assumed correspondence between the first assumption and the second and third, arguing that '[t]his altruistic stance ... is unsustainable and ultimately undesirable because it tends to collapse into asceticism and lead to "teacher burnout."' Instead, Higgins argues that '[g]ood teaching requires self-cultivation rather than "self-sacrifice"' (2003: p. 131).

Assuming that there is an inherent conflict between benevolence and self-cultivation seems to have the unfortunate consequence of pitting the well-being of the teacher against the wellbeing of the students. By doing so, it entrenches the commonsensical notion that education is either student-centered (and therefore automatically good) or teacher-centered (and therefore automatically bad). As Avi I. Mintz argues, however, this risks leading to an overly simplified understanding of learning where 'genuine learning is exciting and pleasurable (not joyless or painful)' (2012: p. 249). This is problematic as it assumes that learning should be devoid of painful and frustrating experiences as these are taken to inhibit rather than enable learning. Mintz concludes that the unfortunate dichotomization of learning and discomfort being an effect of the progressive ideal of student-centeredness - 'has led to contemporary classrooms in which students are denied meaningful challenges and deprived of important educational experiences' (pp. 249-250). Similarly, Mark E. Jonas (2010) argues that the widespread fear of inflicting pain in contemporary classrooms may turn out to hamper the student's development of self-mastery rather than strengthen it. While pain is obviously not an end in itself, an education sanitized from discomfort risks producing 'weak-willed conformists who are directed by the whims of their desires and the whims of their cultures' desires’ (p. 49).

In a time when education is frequently embedded in a logic of economic progress (Gilead, 2012), the service-minded and self-sacrificing teacher - seeking above all to alleviate the discomfort of the student-consumer - will find his or her work being oriented around an individualistic preference-satisfying notion of well-being. One of the problems with framing education within an understanding of well-being grounded in economic terms is that whereas the standard economic understanding of well-being assumes that (1) 'preferences are stable' and (2) 'that preferences are to be taken as given' (p. 115), it is, from an educational perspective, reasonable to believe that the satisfaction of preferences in fact needs to be preceded by a laborious process of education. In addition, it is also quite reasonable to argue that whereas economic progress relates to well-being in terms of more or less temporary individual preferences, education needs to be grounded in a more sustainable and less instrumental conception of well-being so as not to simply validate the expressed preferences of the students. Accordingly, John White suggests that ' $[\mathrm{t}]$ he individual on his or her own is not the final authority on what counts as his or her flourishing. There is a centuries-long continuous tradition of thought about this topic to guide us' (2002, p. 452). Arguably, gaining an understanding of this tradition of thought will help students come to see what well-being can entail beyond the satisfaction of temporary wants, and it can help them reassess their preconceived preferences and set them on the path to striving for a more tenable form of wellbeing.

The economization of well-being in education may serve to illuminate the problem of egoism to the extent that it opens up for a discussion on rational versus irrational self-seeking. It is 
obvious that if the prevailing notion of well-being in education is informed by a logic of economic progress then the self-seeking teacher comes across as nothing above or beyond a self-absorbed and small-minded person indulging in a kind of irrational self-seeking. If, however, the notion of well-being appealed to is grounded in rational self-seeking then it becomes possible to conceive of the teacher's and the student's self-seeking as being coextensive and as mutually empowering, making it rational from the point of view of the wellbeing of society at large. A teacher motivated by rational self-seeking, in this sense, would endeavor to teach students about the world, not primarily in order to satisfy various temporary wants or preferences (either those of students or him- or herself), but in order to help them come to see how their personal well-being is fundamentally conditioned by, and intertwined with, the well-being of others. As Higgins (2003) notes: 'Because the enterprise of education is a deeply ethical project, intended to help students flourish, it is easy to forget that the practice of teaching is itself a project for the teacher, part of the teacher's quest to lead a good life' (p. 135).

It is a kind of egoism that recognizes that the well-being of the teacher is dependent upon the well-being of the students insofar as students guided by reason will tend to strive for things that may be shared by all (such as an increased understanding) rather than things that are in competition (such as esteem). If the good is conceived as limited and available only to some, it will cause conflicts and it will give rise to jealousy and hatred, pitting people against one another in the striving for the good. If, however, the good is conceived as unlimited and available to all there is no reason to compete over it but all the more reason to strive collectively for it. It follows that rational and irrational self-seeking are differentiated by the kinds of goods they are directed at and the different kinds of well-being these goods correspond with. It is important, then, to distinguish between these different kinds of wellbeing when taking on the question of egoism in education.

Spinoza offers an understanding of rational self-seeking in the sense just described. In fact, for Spinoza the well-being of society is conditioned by the self-seeking of the individual, provided that this self-seeking is guided by a rational understanding of virtue. Elsewhere I have argued that while Spinoza's ethical theory may not lend itself as a model for moral education (because it lacks some key characteristics typically required by moral education) it certainly does open up for a decidedly moral account of education (Dahlbeck, 2016a; Dahlbeck, 2016b). Since Spinoza's ethical theory is conditioned by his psychological egoism, however, it is necessary to unpack Spinoza's psychology before we begin investigating its implications for education in general and the relation between the well-being of the teacher and the student in particular. In what follows I will therefore lay out the basics of Spinoza's psychological and ethical egoism, in order to then investigate how the notion of the egoistic teacher follows from this. Having done so I aim to draw some preliminary conclusions regarding the role of egoism in education more broadly, so as to establish an ethical account of education grounded in, rather than conceived as an antidote against, the egoism (qua rational self-seeking) of the teacher and the students. 


\section{Spinoza's Psychological and Ethical Egoism: Self-Preservation as the Foundation of Virtue}

The striving to persevere in existence is the essence of every finite thing according to Spinoza's conatus doctrine (E3p6, E3p $7^{1}$ ). A human being, being one such finite expression or mode of substance (God or Nature), is therefore determined by its nature to seek out things that will aid in this striving for perseverance and to avoid things that hinder it. This striving is the fundamental motivation for everything we do. Spinoza's understanding of striving is nonintentional and it is causally determined. It is therefore not conceived in terms of a free will intervening with natural causation but may be best understood like this: 'Acorns strive to become trees, not in the sense they intend or plan to become trees, but rather in the sense that acorns causally act to bring about changes such that they become trees' (Kisner, 2011, p. 88). It follows from this that striving for Spinoza, as for Descartes, is a non-psychological notion and it describes 'what a given object will do unless prevented by external causes' (Della Rocca, 1996, p. 195).

Self-preservation, in Spinozistic terms, is not a matter of mere survival. It indicates, rather, the degree of power with which we exist in the present. To exist, for Spinoza, is a gradual notion where our degree of existence corresponds with the degree to which we can cause things (including our ideas). To be able to cause something, in turn, means understanding something fully. The more things we understand, the more we can cause and the more we exist. We strive, then, to understand things better so that we can be the cause of our ideas so that we can strive with a greater degree of power. Spinoza's naturalistic ethics thereby equates power with virtue. In E4D8 Spinoza writes: 'By virtue and power I understand the same thing, that is (by 3p7), virtue, insofar as it is related to man, is the very essence, or nature, of man, insofar as he has the power of bringing about certain things, which can be understood through the laws of his nature alone.' It follows from this that Spinoza's notion of perfection is of a fully existing thing - a thing that is fully self-explained and fully self-caused. The only thing that can be said to exist fully in this sense is God or Nature - Spinoza's substance (E1p14 by E1D1, E1D3). Everything else is, to different degrees, externally caused (E1p15d by E1D5). To the extent that we strive to exist more, then, we also strive to perfect ourselves (in relation to the posited model of a fully existing thing) and we do this by seeking to become more self-determined vis-à-vis external causes.

For Spinoza, our natural striving for self-preservation is the only foundation of virtue (E4p22c). On Spinoza's view, 'we neither strive for, nor will, neither want, nor desire anything because we judge it to be good; on the contrary, we judge something to be good because we strive for it, will it, want it, and desire it' (E3p9s). This means that moral concepts like good and evil are not objective standards for Spinoza but rather modes of thought serving to facilitate our striving for whatever furthers our self-preservation. We need these psychological labels because we often mistake things that are bad for us (things that may give us temporary pleasure but that are ultimately detrimental for our striving to persevere) for things that are truly good for us (things that give us lasting joy). Standards of good and evil (or good and bad) may serve to help us recognize what we should strive for if we follow the guidance of reason rather than our passive responses to external stimuli.

\footnotetext{
${ }^{1}$ Passages in Spinoza's Ethics will be referred to using the following abbreviations: a(-xiom), c(-orollary), d(-emonstration), D(-efinition), p(-roposition), s(-cholium) and pref(-ace). DOA refers to $\mathrm{D}$ (-efinition) $\mathrm{O}(-\mathrm{f})$ the A(-ffects). Hence, E4p22c refers to the corollary of the $22^{\text {nd }}$ proposition of part 4. All references to the Ethics are to Curley's (1985) translation.
} 
This may seem paradoxical insofar as it indicates that there actually are objective standards of good and evil, where whatever benefits our striving to persevere is good (E4p31) and whatever hinders this striving is bad (E4p30). Since these things are not good and evil in themselves, however, but only insofar as they agree or disagree with our nature (which will differ), standards of good and evil are always relative to a particular thing striving for more power. From the eternal perspective of God or Nature objective moral labels make no sense since 'nothing happens in Nature which can be attributed to any defect in it, for Nature is always the same, and its virtue and power of acting are everywhere one and the same' (E3pref). Morality is therefore contingent upon something striving for perfection and since different things do this in different ways and benefit from different things (at different times) it is impossible to determine a moral standard to fit all finite things regardless of when and where they are. In the preface to Part 4 of the Ethics Spinoza explains:

As far as good and evil are concerned, they also indicate nothing positive in things, considered in themselves, nor are they anything other than modes of thinking, or notions we form because we compare things to one another. For one and the same thing can, at the same time, be good, and bad, and also indifferent. For example, Music is good for one who is Melancholy, bad for one who is mourning, and neither good nor bad to one who is deaf. (E4pref)

When we recognize what is truly good for us this will have the benefit of making us more powerful, as it will mean that we can join with others benefitting from the same thing. The notion that a joint striving is beneficial for the egoistic striving of the individual is suggested by Spinoza in E4p18s:

For if, for example, two individuals of entirely the same nature are joined to one another, they compose an individual twice as powerful as each one. To man, then, there is nothing more useful than man. Man, I say, can wish for nothing more helpful to the preservation of his being than that all should so agree in all things that the minds and bodies of all would compose, as it were, one mind and one body; that all should strive together, as far as they can, to preserve their being; and that all, together, should seek for themselves the common advantage of all.

If we strive for things that are in competition - such as money or reputation - we will end up struggling over them, but if we recognize that what is truly good for us are things that are not in competition we will come to see that we can be strengthened in our own striving by joining with others striving for the same thing. The best thing we can strive for, as rational beings, is understanding and for Spinoza an adequate understanding of the world is '[t]he absolute virtue of the mind' (E4p28d). When we strive for understanding collectively we will be strengthened in our egoistic striving. Spinoza's argument for why this is so - as hinted at in the above quoted passage from E4p18s - hinges on his understanding of the relative complexity of bodies and thoughts.

The Relative Complexity of Bodies and Thoughts: Spinoza's Understanding of the Unity of Simpler and More Complex Bodies and their Corresponding Ideas

A body for Spinoza is defined by relations of motion and rest. Simple bodies are composed of extended parts that maintain a stable relation of motion and rest and that can affect and be 
affected by external bodies. More complex bodies are similarly composed, but because they are made up of many more interacting parts, they have more capacity of affecting and being affected by other bodies. Even complex bodies, however, can join together and function like a single body, providing that they strive for (and benefit from) the same things. The way to determine whether individual parts (however complex) make for a single body depends on whether or not they are organized in such a way as to bring about effects resulting from their unified effort. As we saw above, all bodies - from the simplest to the most complex - are striving to persevere in existence. Accordingly, if whatever benefits my striving for perseverance is also beneficial for someone else (being like me) we may join together in this striving for the same thing, which, as Genevieve Lloyd points out, goes to illustrate the 'overtones of unavoidable sociability' (1998, p. 160) of Spinoza's understanding of an individual body. Bodies that are unlike my own, in contrast, pose a threat insofar as they also strive for self-preservation and insofar as their self-preservation threatens to diminish my power of acting. In order to strengthen my own power of acting vis-à-vis external bodies I therefore need to find ways of striving collectively, while still being motivated by egoism. Because bodies are dependent upon other bodies for their striving to persevere in this sense, individual bodies are always caught up in - and determined by their position in - complex causal networks of other bodies that they affect and are affected by.

Famously, Spinoza subscribes to a form of parallelism maintaining that ' $[\mathrm{t}] \mathrm{he}$ order and connections of ideas is the same as the order and connection of things' (E2p7). Body and mind (extension and thought) are understood as parallel attributes expressing the same substance - God or Nature - in two different ways (E2p7s). Spinoza's parallelism dictates that ' $[\mathrm{t}]$ he human mind is capable of perceiving a great many things, and is the more capable, the more its body can be disposed in a great many ways' (E2p14). This means that the ethical striving for self-preservation (whether perceived via the attribute of extension or thought) is always conditioned by external bodies and thoughts insofar as these can either hinder (when incompatible) or aid (when compatible) the striving of the body/mind in question. As Spinoza explains in E4p18s (quoted above), the more we can join with others who are like us, the more powerful we can become in our own striving and we are therefore more likely to be successful in our egoistic striving for self-preservation. Simply put, successful selfpreservation, for Spinoza, hinges on our ability to join with others. Spinoza's ethical perfectionism $^{2}$ is therefore both fundamentally egoistic - insofar as we always strive to preserve ourselves - and fundamentally social - insofar as we can only do this successfully when we join with others striving for the same thing.

Even if successful self-preservation is at once motivated by egoism and conditioned by a collective sense of striving, it is still not entirely clear whether the teacher and his/her students really can be said to compose a complex body/mind in the ontological sense described above. While we will return to this important question in the concluding part of this paper, it should be noted here that even if this is not the case, benevolence will still play a crucial role for the egoistic striving of the teacher.

\footnotetext{
${ }^{2}$ Michael LeBuffe, for example, argues that Spinoza is a perfectionist in the sense that his moral theory 'includes an account of human essence; an account of value in terms of the improvement of some or all of the properties that constitute essence; and a defense of this account of value against other comprehensive accounts as the account that best coheres with our intuitive moral judgments' (2010, p. 317).
} 


\section{The Merging of Egoism and Altruism: Benevolence without Pity}

Spinoza defines benevolence as 'a desire to benefit one whom we pity' (E3DOA 35). Pity, in turn, is understood as a form of sadness 'accompanied by the idea of an evil which has happened to another whom we imagine to be like us' (E3DOA 18). Benevolence, from this perspective, results in a form of sadness, which for Spinoza is equivalent to a diminishing of our power of acting. However, Spinoza also offers another understanding of benevolence, one that is not negative in the sense that it results in a diminishing of our power to act. When benevolence is understood as a desire to help others that originates from our rational striving to persevere in being it is empowering rather than disempowering. Accordingly, in E4p37, Spinoza writes that '[t]he good which everyone who seeks virtue wants for himself, he also desires for other men,' and in E4p37s1, that 'he who strives from reason to guide others acts not by impulse, but kindly, generously, and with the greatest steadfastness of mind.' It is this latter understanding of benevolence that is perfectly compatible with Spinoza's psychological egoism as outlined above. In fact, when we aid others in their striving for something good we will also be aided through this endeavor. The link between the egoistic striving for selfpreservation and the flourishing of the greater community may therefore be identified as a rational form of benevolence through which a person can be empowered by aiding others in their striving. Spinoza scholar Steven Nadler explains that a virtuous person

will treat others in such a way that their own conatus or power of acting is increased (which is what virtue is) and that their life is thereby improved. And he will do so because he, egoistically motivated that he is, recognizes through reason alone that it is to his own benefit to do so. (Nadler, 2014, pp. 50-51)

Spinoza's conception of egoism guided by reason clearly illustrates how egoism and altruism (without pity) collapse into the same thing and it also motivates why we need to form collective concepts of the good so that we can strive for the same things without posing a threat to one another. As Don Garrett points out, since self-seeking is conditioned by benevolence, Spinoza 'need not deny the phenomena of altruism. He is committed only to the view that the causal origins of these phenomena always lie in a single psychological force, which is the individual's own endeavor for his or her own self-preservation' (Garrett, 1996, p. 303). Placed in an educational context, Spinoza's ethical and psychological egoism illustrates how - even though the motivation for teaching and being educated springs from the egoistic desire to strive for more power - the educational relation is always framed by a collective striving for the good life where rational benevolence has a central position. This allows us to conceptualize the role of the teacher as a self-seeking teacher without assuming that this selfseeking needs to be carried out at the expense of the students. On the contrary, from a Spinozistic point of view, the self-seeking of the teacher is conditioned by the rational striving of his or her students for the same thing. ${ }^{3}$ For this to be possible, however, the teacher must first ensure that the students strive for things that are certainly good - i.e. things that are conducive to an increased understanding of themselves and the world - rather than things that will end up corrupting the community by spreading envy and hatred.

\footnotetext{
${ }^{3}$ It should be noted that while it is the same thing in the sense that it is beneficial for selfpreservation it may well be different in the sense that different people benefit from different things.
} 


\section{Spinoza's Theory of the Affects and the Role of Desire in Education}

How then can the teacher see to it that students recognize and strive for things that are certainly good for their striving for self-preservation? To answer this question we need to look closer at Spinoza's conception of the relation between our natural striving for things that benefit us and our recognition and understanding of these things. We have already seen that we strive - by our very nature - to persevere in being and that because of this, what is objectively good is simply whatever enables and enforces this striving. We have yet to see, however, what it means to recognize the good and how this recognition relates to the striving to persevere specifically. For Spinoza, human psychology is best understood in terms of affects and affectivity. Affects, in brief, are changes in the striving to persevere (E3D3). When we encounter something that overpowers us, our power of acting is diminished and this diminishing, in turn, is experienced as an affect of sadness. Correspondingly, when we encounter something that we overpower, our power of acting is increased and this increase is experienced as an affect of joy. When we respond passively to external bodies we sometimes experience joy and we sometimes experience sadness, depending on the power of the external bodies we encounter. The problem with passive affects, as Spinoza sees it, is that we can never really know whether or not they will result in joy or sadness. All we can ever really do is to hope for encounters that will result in joy and try to avoid things that we fear will result in sadness. Without a good idea of which encounters will give rise to affects of joy and which will give rise to affects of sadness, however, we will be condemned to an unstable life governed by our 'hopes and fears in the face of the vicissitudes of nature and the unpredictability of fortune’ (Nadler, 2011, p. 31).

In an educational setting this can be exemplified by the benefits of allowing students to experiment with their affective responses to different social environments. This may be staged by the teacher where he/she can arrange for situations where students can be protected from the most powerful passive affects while at the same time being exposed to some of the more frequent temptations and emotional threats of everyday life. These threats can then be approached in a structured and methodical way so as to allow students to understand them in terms of affective changes and to practice on breaking chains of association that cause them to suffer unduly. In E5p4s Spinoza describes this process where he encourages us to 'take special care to know each affect clearly and distinctly' so that 'the affect itself may be separated from the thought of an external cause and joined to true thoughts.' This educational approach is reminiscent of contemporary social psychology in so far as it aims at helping students become competent in judging which social environments they benefit from and which environments they would do best to avoid. Accordingly, it involves cultivating a form of situational awareness that may be described as follows: 'That is, I have changed my own environment so I am able to exhibit the regularities in behaviour I desire, and avoid environments that will disenable my control' (Samuels \& Casebeer, 2005, p. 79). This requires understanding the affective changes that result from encounters with different things. Since different students will respond differently to different things it involves practical experimentation in combination with an effort to understand how different things give rise to different affective responses.

Affects can also be active however. When an affect is active it is always an affect of joy as it is an affect that is caused internally rather than externally. For an affect to be caused internally means that it is properly understood. For Spinoza, being something's cause is coextensive with properly grasping its chain of causation. Accordingly, in E3D1 Spinoza defines an adequate cause as follows: 'I call that cause adequate whose effect can be clearly 
and distinctly perceived through it.' Our degree of activity therefore hinges on our degree of understanding. It follows from Spinoza's psychological theory of the affects that the ethical goal of increasing our power of acting is always conditioned by the extent to which we understand things properly.

Besides the primary affects of joy and sadness Spinoza also posits a third primary affect in the form of desire. Desire describes our conatus - our striving for self-preservation - together with the consciousness of our conatus (E3p9s). As Michael Della Rocca explains it, 'the mind's desire is simply the tendency to come to have an idea of a more powerful bodily state, a state that itself is a more powerful state' (2008, pp. 157-158). Our desire is what prompts us to 'strive to further the occurrence of whatever we imagine will lead to joy, and to avert or destroy what we imagine is contrary to it, or will lead to sadness' (E3p28). This basic psychological schema explains the importance of forming adequate ideas of things insofar as these ideas can serve the ethical purpose of letting us know, with some degree of certainty, which encounters will lead to joy and which will lead to sadness. It also goes to illustrate the importance of what Heidi M. Ravven (1990) has termed 'the education of desire,' whereby we can begin to enhance the rational understanding of what we should strive for so as not to strive for things that will turn out to diminish our power of acting.

In order to situate the education of desire in an educational context we might think of the extent to which students (and people in general) tend to attribute their affective state to external things. For instance, an unforeseen change of events, such as an unannounced delay in the morning traffic, may trigger a series of passive responses that have effects long after the actual event has passed. Rather than dwelling on the things that may or may not have caused the delay to begin with (causes that will never be available to us in their entirety), educating the desire can help students see that their affective responses are not caused by external things in themselves, but by their desires in combination with their beliefs about the external things (Ravven, 1990). Redirecting their desires toward their own beliefs about things (rather than the things in themselves) may help them disconnect the affects from ideas of external causes so that 'the love, or hate, toward the external cause is destroyed, as are the vacillations of the mind from these affects' (E5p2). This way passive affects - resulting from encounters with external things - can be turned into active affects.

Since affects, qua changes in the conatus, and knowledge of the affects are identical for Spinoza (E4p8, E4p64d), it is clear that learning to understand the good better is both a means to an end (of becoming more active) and an end in itself, insofar as gaining knowledge of an affect of joy equals experiencing joy. As Eugene Marshall writes: 'When we know good and evil, which, for Spinoza, involves knowing what is beneficial or harmful to us, we are in fact experiencing affects of joy or sadness' (2013, p. 126-127). The task of the teacher, then, is not simply to inculcate moral behavior in students by offering moral decrees to abide by passively, but to help students acquire a reliable understanding of what will benefit their striving for perseverance and what will threaten it. The education of desire is therefore a central part of rational self-seeking as it concerns forming reliable ideas of things to strive for. While the different things that students benefit from may not amount to the same thing (insofar as students are not precisely the same) it is nevertheless crucial that the teacher helps them see the difference between things that truly do benefit their striving for self-preservation and things that do not. Of course, many things may benefit their striving for self-preservation and different things will surely benefit different students at different times. As long as these different things are understood according to an educated desire, however, they will tend to 
strengthen the natural striving for self-preservation and as long as they do, it is in the selfinterest of the teacher to help students identify them with some degree of precision.

\section{The Self-Seeking Teacher: An Ethical Account of Teaching}

Depending on how we understand the goal of our ethical striving - in terms of the satisfaction of our temporary preferences or in terms of a more eudaimonistic understanding of well-being - the concept of egoism in education will take on radically different meaning. Self-seeking can either be guided by a misconceived understanding of what is good - where whatever things I happen to desire for the moment guides my striving - or by a rational understanding where I come to see that whatever is beneficial for other people striving for a rational understanding of the good is also beneficial for me.

The ethical task of the teacher - understood from this latter perspective - becomes one of unifying the will of the students (by helping them come to understand what they benefit from qua rational beings) so that the greater social body may become more empowered, thereby aiding all of the individuals striving for a better understanding of themselves and what they benefit from. Again, this hinges on Spinoza's understanding of the composition of more or less complex bodies, and so from a Spinozistic perspective, it makes sense to understand the ideal collective (such as a group of students and their teacher) as being made up of parts of a larger and more complex body that strive collectively and that communicate motion to one another in a unified manner producing certain effects. The teacher, in this conception, corresponds with Spinoza's understanding of the sovereign in the ideal state. Both make for a single locus of power through which all the different motions of its many parts are being directed and orchestrated (provided that they strive for the same things). This comparison relies on a decidedly social understanding of the will. Michael Rosenthal explains:

Like the sovereign, who decrees a law but who depends on the concerted action of all its subjects to enact it in practice, the will appears to express a singular action, but it actually expresses the united action of the multiple discrete individual things that constitute the parts of the whole through the regular communication of motion to one another. (Rosenthal, 2014, p. 97)

Egoism, when understood in a context where even the will of the individual is conceived as a socially constituted expression of many different parts interacting so as to produce an effect, is just as bound up with external forces as anything else. In itself, it is neither good nor bad but simply an expression of an individual striving for self-preservation. In an educational context, it can be either productive or detrimental (for teacher and students alike) depending on whether it is guided by a rational understanding of what to strive for collectively or by the misconception that true goods are in competition.

There is a sense in which we must tread very carefully here. It is by no means clear that we should understand the social body of the students and their teacher in terms of an individual in a literal or ontological sense as implied in the example above. Opinions differ as to how Spinoza treats social bodies like the state that, while ideally may be composed like a literal individual, more often tends to function like a metaphorical individual (insofar as they may be compared with, but seldom function like, an individual in an ontological sense). While the students and their teacher may be said to make for a unified body/mind in a literal sense insofar as they strive collectively and insofar as they benefit from the same things and give rise to unified effects, this may be best approached in terms of an ideal that no group of 
people can ever hope to live up to. It is useful to take a closer look at the example of Spinoza's ideal state. Spinoza posits an ideal state that functions like an individual in an ontological sense (TTP, Ch. 5.20; TP, Ch. 5.6; E3p7s2 ${ }^{4}$ ). That is, it may be described as an individual comparable to an individual human being only much more complex (see Zac, 1963; Matheron, 1969; Kwek, 2015). This state, however, presupposes fully rational citizens that strive collectively with a unified will. Since humans, as we have seen, are always to some extent determined externally there is no good reason to believe that they will ever come to be similar enough to function like a literal individual. Spinoza is quite clear that the ideal state is unrealistic (TTP, Ch. 5.21-22; TP, Ch. 6.3) as the fully rational (i.e. completely selfdetermined) person is an equally unattainable ideal. For this reason, some commentators have argued that Spinoza's state should be taken as an individual in a metaphorical rather than a literal sense (McShea, 1975; Den Uyl, 1983; Rice, 1990).

While the literalist interpretation of a social body like the state can illustrate how the relation between parts and whole in the individual human corresponds with the composition of the state (and how the individual parts cooperate in both so as to produce unified effects), it becomes more difficult to identify a unifying principle underlying the striving for selfpreservation in relation to the state. Since the essence of every individual is its conatus, the literal understanding of a social body needs to posit that it is kept together by this unifying principle of self-preservation and that it cannot be destroyed by itself (but only by being overpowered by external bodies) (E3p4). For example, a group of people may join together in the shifting of a large rock but as soon as the rock is successfully moved they can disperse the group and focus instead on their individual affairs. A literal individual cannot dissolve itself at will for the simple reason that its defining characteristic is the ability to hold together its many different parts throughout internal and external changes. In this sense a microbe (living in the bloodstream) is a literal individual that is part of the greater individual of the bloodstream. The bloodstream, in turn, is part of the greater individual of the human being which is part of an ecosystem and so on. A social body, however, is not an individual in this literal sense since it cannot be derived from natural laws that dictate its striving for self-preservation in the same way as an ecosystem.

This, then, poses a severe challenge for the argument that the teacher and his/her students make for an individual in a literal sense. In extension, if the notion of the egoistic teacher (in the Spinozistic sense) hinges on the assumption that teacher and students make up an individual in a literal sense then this would appear to be a substantial weakness in the argument. I believe there is a way out of this conundrum however. I would argue that if we take the teacher and his/her students to be an individual in a metaphorical sense instead, we can still benefit from the understanding of the relative complexity of bodies/minds without having to assume that a social body (whether it's a state or a group of students) can ever become fully unified in this ontological sense. All we have to do is illustrate why it may still be beneficial for this group of different people to strive for similar things (and how this striving is motivated by rational egoism), insofar as people are similar enough to benefit from general things like an increased understanding but different enough to have to come to find out what this means more specifically in any given situation.

\footnotetext{
${ }^{4}$ All references to Spinoza's Theological-Political Treatise (TTP) and the Political Treatise (TP) are to Curley’s (2016a; 2016b) translations.
} 
In this sense, a Spinozistic understanding of teaching as an egoistic yet rational endeavor may serve to offer a much needed alternative to the altruistic and self-sacrificing ideal in education without at the same time furthering an irrational (i.e. harmful to others) understanding of selfseeking. By doing so, it may also serve to offer a useful counter-image to the preferencesatisfying notion of well-being commonly assumed in an educational discourse embedded in a logic of economic progress (Gilead, 2012). The very purpose of education, from a Spinozistic point of view, is to come to find out what we benefit from are and to endeavor to align our understanding of this with the understanding of those striving for the same thing so that we become empowered rather than disempowered as a social body. It is only when we understand what we benefit from more clearly (and thereby what it is rational to strive for) that we can claim to be educated. The teacher is pivotal in this process as he or she plays the part of a role model illustrating the many benefits of rational self-seeking. It is also the task of the teacher to unify the will of the students - even if this will is understood in the metaphorical rather than the literal sense - so they can come together as a single expression of power. Instead of assuming that what we already want is what we benefit from, education should therefore begin by asking us: what is it that you truly need and how can you best obtain it?

\section{References}

Dahlbeck, J. (2016a) Spinoza and Education: Freedom, Understanding and Empowerment. London \& New York: Routledge.

Dahlbeck, J. (2016b) A Spinozistic model of moral education, Studies in Philosophy and Education, EarlyView: pp. 1-18. Doi: 10.1007/s11217-016-9530-7

Della Rocca, M. (2008) Spinoza. London: Routledge.

Della Rocca, M. (1996) Spinoza's metaphysical psychology. In D. Garrett (Ed.), The Cambridge Companion to Spinoza (pp. 192-266). Cambridge: Cambridge University Press.

Den Uyl, D. J. (1983) Power, State and Freedom: An interpretation of Spinoza's Political Philosophy. Assen, The Netherlands: Van Gorcum \& Company.

Garrett, D. (1996) Spinoza's ethical theory. In D. Garrett (Ed.), The Cambridge Companion to Spinoza (pp. 267-314). Cambridge, Cambridge University Press.

Gilead, T. (2012) Education and the logic of economic progress, Journal of Philosophy of Education, 46(1): 113-131.

Higgins, C. (2003) Teaching and the good life: a critique of the ascetic ideal in education, Educational Theory, 53(2): 131-154.

Higgins, C. (2011) The Good Life of Teaching: An Ethics of Professional Practice. Malden, MA: Wiley-Blackwell.

Jonas, M. E. (2010) When teachers must let education hurt: Rousseau and Nietzsche on compassion and the educational value of suffering, Journal of Philosophy of Education, 44(1): 45-60. 
Kisner, M. J. (2011) Spinoza on Human Freedom: Reason, Autonomy and the Good Life. Cambridge: Cambridge University Press.

Kwek, D. H. B. (2015) Power and the multitude: A Spinozist view, Political Theory, 43(2): 155-184.

LeBuffe, M. (2010) Spinoza's perfectionism, History of Philosophy Quarterly, 27(4): 317333.

Lloyd, G. (1998) Spinoza and the education of the imagination. In A. O. Rorty (Ed.), Philosophers on Education: New Historical Perspectives (pp. 156-171). London \& New York: Routledge.

Marshall, E. (2013) The Spiritual Automaton: Spinoza's Science of the Mind. Oxford: Oxford University Press.

Matheron, A. (1969) Individu et Communauté chez Spinoza. Paris: Les Editions de Minuit.

McShea, R. J. (1975) Spinoza, human nature, and history. In M. Mandelbaum \& E. Freeman (Eds.), Spinoza: Essays in Interpretation (pp. 101-116). LaSalle, Ill: Open Court Publishing.

Mintz, A. I. (2012) The happy and suffering student? Rousseau's Emile and the path not taken in progressive educational thought, Educational Theory, 62(3): 249-265.

Nadler, S. (2011) A Book Forged in Hell: Spinoza's Scandalous Treatise and the Birth of the Secular Age. Princeton, NJ: Princeton University Press.

Nadler, S. (2014) The lives of others: Spinoza on benevolence as a rational virtue. In M. J. Kisner \& A. Youpa (Eds.), Essays on Spinoza's Ethical Theory (pp. 41-56). Oxford: Oxford University Press.

Ravven, H. M. (1990) Spinoza's materialist ethics: the education of desire, International Studies in Philosophy, 22(3): 59-78.

Rice, L. C. (1990) Individual and community in Spinoza's social psychology. In P-F Moreau \& E. Curley (Eds.), Spinoza: Issues and Directions (pp. 271-285). Leiden: E. J. Brill.

Rosenthal, M. A. (2014) Politics and ethics in Spinoza: the problem of normativity. In M. J. Kisner \& A. Youpa (Eds.), Essays on Spinoza's Ethical Theory (pp. 85-101). Oxford: Oxford University Press.

Samuels, S. M., \& Casebeer, W. D. (2005) A social psychological view of morality: why knowledge of situational influences on behaviour can improve character development practices, Journal of Moral Education, 34(1): 73-87.

Spinoza, B. (1985) Ethics. In E. Curley (Ed. and trans.), The collected works of Spinoza, Vol. 1 (pp. 408-617). Princeton: Princeton University Press.

Spinoza, B. (2016a) Theological-Political Treatise. In E. Curley (Ed. and trans.), The 
Collected Works of Spinoza, Vol. 2 (pp. 65-354). Princeton: Princeton University Press.

Spinoza, B. (2016b) Political Treatise. In E. Curley (Ed. and trans.), The Collected Works of Spinoza, Vol. 2 (pp. 503-604). Princeton: Princeton University Press.

White, J. (2002) Education, the market and the nature of personal well-being, British Journal of Educational Studies, 50(4): 442-456.

Zac, S. (1963) L’idée de vie dans la philosophie de Spinoza. Paris : PUF. 